\title{
Preparation of Charcoal Using Flower Waste
}

\author{
Wondwossen Bogale1,2 \\ ${ }^{1}$ University Industry Linkage and Technology Transfer, Addis Ababa University, Addis Ababa, Ethiopia \\ ${ }^{2}$ Addis Ababa Institute of Technology, Addis Ababa, Ethiopia \\ Email: wondwossenboge@gmail.com
}

How to cite this paper: Bogale, W. (2017) Preparation of Charcoal Using Flower Waste. Journal of Power and Energy Engineering, 5, 1-10.

https://doi.org/10.4236/jpee.2017.52001

Received: November 22, 2016

Accepted: February 4, 2017

Published: February 7, 2017

Copyright $\odot 2017$ by author and Scientific Research Publishing Inc. This work is licensed under the Creative Commons Attribution International License (CC BY 4.0).

http://creativecommons.org/licenses/by/4.0/ (c) (i) Open Access

\begin{abstract}
Ethiopia is the second largest flower exporter in Africa. However, finding effective solutions for flowers waste management that are economical, efficient and environmentally friendly is a very difficult task. In this paper, a novel technology to recover energy from flower waste with the objective of producing biochar from flower waste by using pyrolysis has been presented. The pyrolysis reactor has been designed, manufactured and tested. Characterization of the flower waste has also been done by estimating the ultimate and proximate analysis. Besides the energy content has been measured by using Bomb calorimeter. Detailed proximate analysis has been performed and the energy content of the biochar has also been measured. The result shows that $10 \mathrm{~kg}$ of biochar is produced by using $18 \mathrm{~kg}$ of flower waste with a conversion efficiency of $55.5 \%$ and approximately $310.8 \mathrm{~kg}$ of biochar can be generated daily. Based on the result, the measured value of lower heating value of the produced biochar is $26.54 \mathrm{MJ} / \mathrm{kg}$ and approximately $392.2 \mathrm{~kg}$ of firewood is replaced daily. Thus, by adopting this innovative technology and producing biochar, the amount of flower waste is reduced from going to the landfill, energy is recovered from flower waste, income is generated from the selling of the produced biochar and the energy problems of the society is solved and finally environmental impact of the flower waste is reduced.
\end{abstract}

\section{Keywords}

Biochar, Briquette, Flower Waste, Pyrolysis

\section{Introduction}

Ethiopia is the second largest flower exporter in Africa, with over 100 flower growers on 1700 hectares [1]. This implies that everyday a huge amount of waste is generated at the flower farm in Ethiopia. However, finding effective solutions for flowers waste management that are economical, efficient and environmentally friendly is a very difficult task. This is due to the fact that flower farmers use 
pesticides and fertilizers to grow the flowers. Therefore, the flower waste will contain those pesticides. This will affect the environment greatly unless appropriate measure has been taken.

Biochar is defined as carbon-rich product obtained when biomass is heated in a closed container with little or no available air through a process called pyrolysis [2]. It has been used for so long since it mitigates climate change and used for sustainable waste management [3]. The biochar produced from agriculture waste is used for soil amendment, as a smokeless fuel, which can reduce the amount of waste to be sent to the landfill. Besides, it is used to improve soil nutrient retention and water holding capacity [2]-[8]. It is known that the main element of biochar is carbon; it also contains hydrogen, oxygen, nitrogen and sulphur [9]. Since biochar has large specific area and porous structure, it has been used as adsorbent for water pollutants [10].

There are several thermal treatment technologies to produce biochar including pyrolysis, gasification, hydrothermal carbonization, flash carbonization and Torrifaction [11] [12] [13]. Among those technologies pyrolysis is the most adopted technology to produce biochar from biomass. Pyrolysis is defined as a process for decomposing organic materials thermally under oxygen-free conditions in the temperature range, $300^{\circ} \mathrm{C}-800^{\circ} \mathrm{C}$ which leads to the production of three main substances, i.e., solid residue (biochar), a liquid product (bio-oil) and non-condensable gas known as Syngas which consist of carbon monoxide (CO), carbon dioxide $\left(\mathrm{CO}_{2}\right)$, hydrogen $\left(\mathrm{H}_{2}\right)$, and methane $\left(\mathrm{CH}_{4}\right)$ [14]. The yields of the pyrolysis products depend on the characteristics of the input biomass materials, the pyrolysis processes adopted and different parameters i.e. reaction temperature, heating rate, and residence time [15]. Based on reviewing different literatures, it has been stated that biochar yield, Syngas yield, ash content, $\mathrm{pH}$, and carbon stability increase with increasing pyrolysis temperature [16] [17] [18]. The pyrolysis process conditions can be optimized to produce either a solid char, gas or liquid/oil product. Depending on the residence time in the reactor pyrolysis is divided into two: slow (long residence time) as shown in Figure 1 and fast pyrolysis (short residence time). Under slow pyrolysis, a biochar yield between $25 \%-35 \%$ can be reproducibly produced depending on the nature of the feedstock, reactor type as well as the degree of operating conditions optimization. To obtain a high bio-oil yield, fast pyrolysis is recommended. However, fast biomass pyrolysis needs to satisfy four conditions namely, a medium temperature $\left(450^{\circ} \mathrm{C}\right.$ $\left.-600^{\circ} \mathrm{C}\right)$, high heating rate $(103-104 \mathrm{~K} / \mathrm{s})$, short vapor residence time $(<2 \mathrm{~s})$ and fast condensation of vapors [17]. Under slow pyrolysis, a biochar yield between $25 \%-35 \%$ can be reproducibly produced depending on the nature of the feedstock, reactor type as well as the degree of operating conditions optimization [18].

In Ethiopia, charcoal is commonly produced using the traditional earth kiln method-earth mound kiln and earth pit kiln; earth mound kiln being the most frequent method with an efficiency of $10 \%-15 \%$ [19]. It has to be noted that high amounts of gases and other unburned hydrocarbons are released into the 


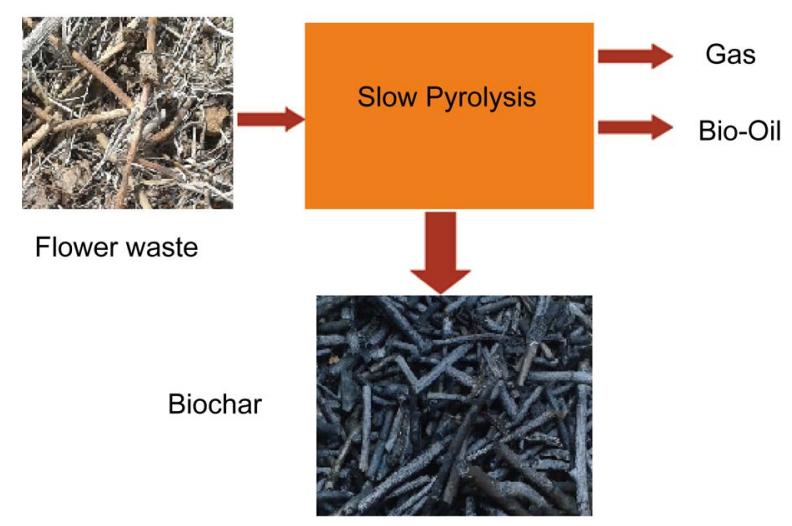

Figure 1. Slow pyrolysis to produce biochar from flower waste [3].

atmosphere. This traditional technology is inefficient and leads to deforestation since most of the people use woody biomass to produce charcoal in Ethiopia. In order to reduce the environmental impact of charcoal using these traditional kilns, new alternatives can be implemented to convert biomass into valuable products. Innovative slow pyrolysis technologies must be adopted in developing countries to produce biochar that is efficient and environmentally friendly. Thus, instead of using woody biomass as the only means to produce biochar in Ethiopia, several biomasses can be used like flower wastes, agricultural wastes, bamboo and others.

Even though biochar has a lot of advantages from energy and environmental perspective point of view, it is has not been used widely in Ethiopia. Most of the biochar reactor that has been used before has low conversion efficiency [20], very small scale and rarely found in rural areas even though $85 \%$ of the population of Ethiopia lives in rural areas. Besides, approximately $90 \%$ of the Ethiopian population used biomass for cooking purpose [21]. This will leads to indoor air pollution and creates healthy problems for the society [22]. However, finding a long-term solution that will solve rural society problem efficiently, economically, and environmental friendly is a very challenging task.

Therefore, in this paper, a novel, efficient and cost effective technology has been designed, manufactured and tested to produce biochar from flower waste. The biochar will be used for various purposes like cooking purpose and for soil amendment. Thus, the waste is converted into an opportunity. Besides, it will help to generate incomes, reduce landfill areas and reduce environmental impact.

\section{Materials and Methods}

First, the flower waste is collected. The leaves are separated from the woody party of the flower waste since the leaves is not used to produce biochar for this research. The woody part of the flower is collected in a daily basis. The mass of the woody part of the flower is measured at wet and dry conditions. Thus, by measuring the flower waste for about 15 days, the average daily dry flower waste is estimated. Data has been collected from one of the flower farms in Ethiopia that 
is generating a daily dry flower waste of $560 \mathrm{~kg}$. The general methodology is shown in Figure 2.

The feedstock used in the study is waste flower from leftover of horticulture farms as shown in Figure 3. The sample has been dried to remove the moisture and cut in small size.

Thermo-chemical behavior of flower waste biomass such as moisture content, ash content, volatile matter and fixed carbon were determined by standard procedures. The moisture content is determined by the loss in weight that occurs when a sample is dried in a laboratory oven at $105^{\circ} \mathrm{C}$ for 1 hour. The volatile matter has been determined by involving measurement of weight loss following combustion of about $1 \mathrm{~g}$ biomass in a furnace at $950^{\circ} \mathrm{C}$ for $6 \mathrm{~min}$. To determine the ash content, the biochar samples were heated in a laboratory ash furnace at $750^{\circ} \mathrm{C}$ for at least 3 hours. The results of the proximate and ultimate analyses of the flower waste are shown in Table 1. The experimental results of the proximate and ultimate analyses of the flower waste are shown in Table 2. The chemical elements, such as carbon, hydrogen, oxygen, nitrogen and Sulfur, that constitute the biomass is estimated by using ultimate analysis. The results of ultimate analysis by using ultimate analyzer are $48.5 \%, 5.8 \%, 42.0 \%, 3.62 \%$, and $0.08 \%$ for contents of carbon, hydrogen, oxygen, nitrogen, and sulphur, respectively as shown on Table 2.

A dried flower waste biomass sample is weighted and placed in a digital Bomb calorimeter for calorific value or heating value determination. The digital Bomb calorimeter is then sealed and the biomass sample is ignited electrically. The complete combustion of the biomass releases heat and it is measured through the temperature change, which is measured by using a digital sensor, of the water bath surrounding the bomb calorimeter. The heat of combustion can be calculated from the resulting rise in temperature. To check the accuracy of heating



Figure 2. General methodology [4].

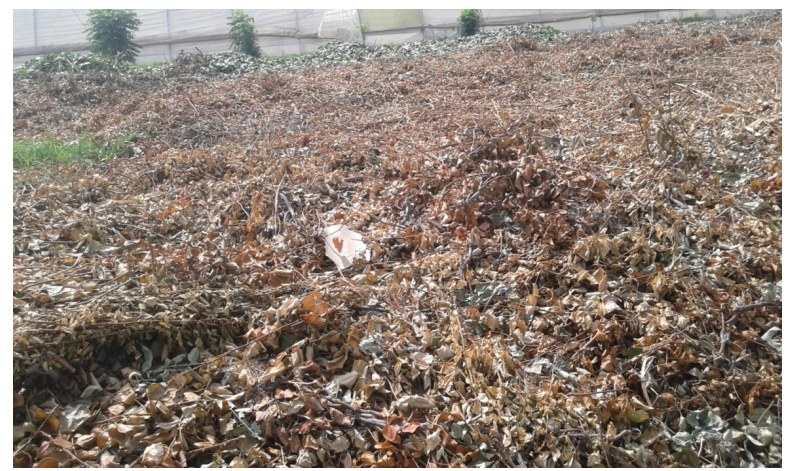

Figure 3. Flower waste [1]. 
Table 1. Final products of biomass during pyrolysis and gasification process [16] [17] [18].

\begin{tabular}{|c|c|c|c|c|}
\hline 冫 & Condition & $\begin{array}{l}\text { Liquid } \\
\text { (bio-oil) }\end{array}$ & $\begin{array}{c}\text { Solid } \\
\text { (biochar) }\end{array}$ & $\begin{array}{c}\text { Gas } \\
\text { (Syngas) }\end{array}$ \\
\hline Fast Pyrolysis & $\begin{array}{l}\text { - } \quad \text { Moderate temperature }\left(\sim 500^{\circ} \mathrm{C}\right) \\
\text { - } \quad \text { Short vapor residence time }(<2 \mathrm{~s})\end{array}$ & $75 \%$ & $12 \%$ & $13 \%$ \\
\hline $\begin{array}{l}\text { Intermediate } \\
\text { Pyrolysis }\end{array}$ & $\begin{array}{l}\text { - Low-moderate temperature } \\
\text { - Moderate hot vapor residence time }\end{array}$ & $50 \%$ & $25 \%$ & $25 \%$ \\
\hline Slow Pyrolysis & $\begin{array}{l}\text { - Low-moderate temperature } \\
\text { - Long residence time }\end{array}$ & $30 \%$ & $35 \%$ & $35 \%$ \\
\hline Gasification & $\begin{array}{l}\text { - } \quad \text { High temperature }\left(>800^{\circ} \mathrm{C}\right) \\
\text { - } \quad \text { Long vapor residence time }\end{array}$ & $5 \% \operatorname{tar}$ & $10 \%$ & $85 \%$ \\
\hline
\end{tabular}

Table 2. Proximate analysis and lower heating value of flower waste.

\begin{tabular}{|c|c|}
\hline \multicolumn{2}{|c|}{ Proximate analysis } \\
\hline Moisture content (wt\%) & 8.335 \\
\hline Ash content (wt\%) & 5.960 \\
\hline Volatile content (wt\%) & 71.310 \\
\hline Fixed carbon (wt\%) & 14.395 \\
\hline \multicolumn{2}{|c|}{ Ultimate analysis (wt\%) } \\
\hline Carbon (wt\%) & 48.5 \\
\hline Hydrogen (wt\%) & 5.8 \\
\hline Nitrogen (wt\%) & 3.62 \\
\hline Oxygen (wt\%) & 42 \\
\hline Sulphur (wt\%) & 0.08 \\
\hline Molecular formula & $\mathrm{C}_{4.04} \mathrm{H}_{5.8} \mathrm{O}_{2.625} \mathrm{~N}_{0.259} \mathrm{~S}_{0.003}$ \\
\hline Lower heating value $(\mathrm{MJ} / \mathrm{kg})$ & $17.9 \mathrm{MJ} / \mathrm{kg}$ \\
\hline
\end{tabular}

values of same samples, few experiments have been repeated. The result is reported as shown in Table 2 .

The heat required for the pyrolysis reactor is supplied by burning a portion of flower waste. This heat is transferred to the reactor to convert waste flower into biochar. The reactor is covered with a refractory coverage to avoid heat loses. Besides, the portion of the produced gas is re-circulated to increase the efficiency of the system. The inside diameter of the reactor is $0.25 \mathrm{~m}$, height of the inside reactor is $1 \mathrm{~m}$. The reactor is a double barrel reactor where the inside one is the pyrolysis reactor and the external one is where combustion is occurring. Air is inserted at the bottom of the combustion chamber. Thus, the heat released from combustion is used for the inside pyrolysis reactor. The sectional view and manufactured prototype of waste flower to biochar reactor is shown in Figures 4-7.

The produced charcoal is mixed with a small amount of molasses. To produce Briquette charcoal a manually operated screw type extruder machine is designed and manufactured as shown in Figure 8. The produced biochar and the main steps till combustion of the biochar are shown in Figure 9. 


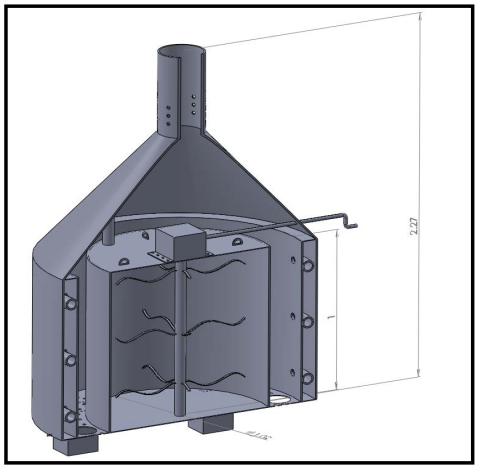

Figure 4. Sectional view of the reactor.

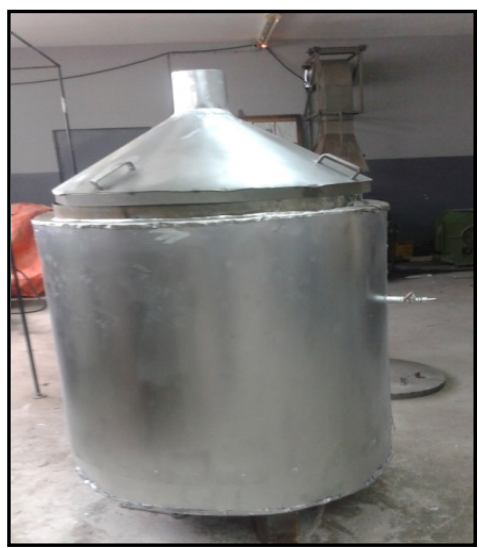

Figure 5. Manufactured prototype.



Figure 6. Inside of the reactor before covering.

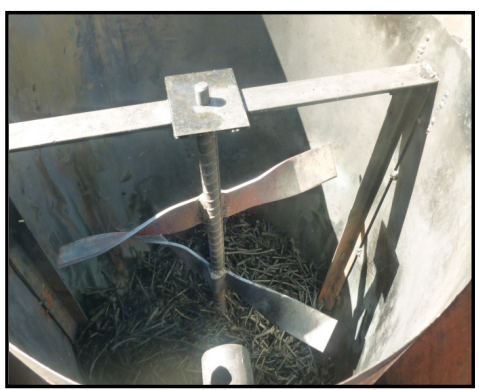

Figure 7. Inside of the reactor with produced biochar. 


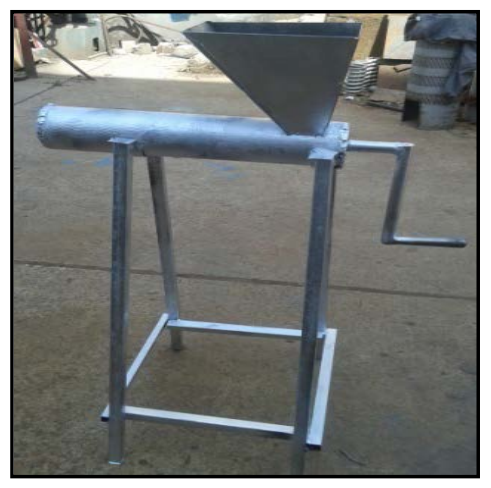

Figure 8. Extruder machine.

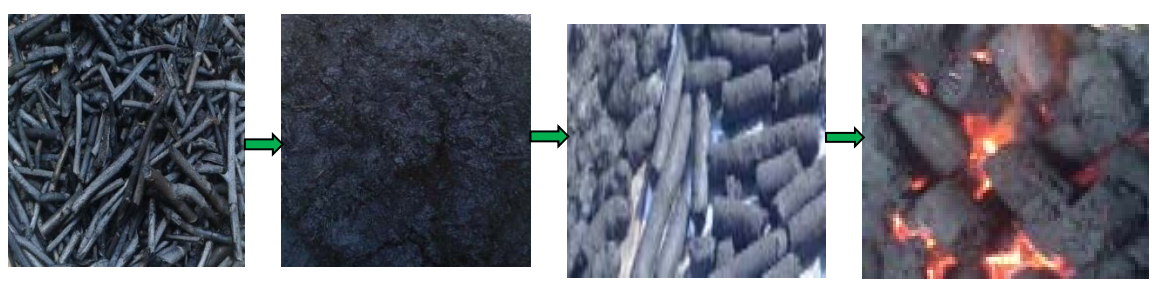

Figure 9. Produced biochar before compaction, mixing, briquette and combustion of biochar [21].

\section{Results and Discussion}

\subsection{Conversion Efficiency}

The conversion efficiency of the biochar reactor has been obtained by the following formulae:

Conversion efficiency $(\%)=$ Flower waste input $\left(\mathrm{W}_{\text {in }}\right) /$ biochar produced $\left(\mathrm{B}_{\text {prod }}\right)$.

The experimental results show that $10 \mathrm{~kg}$ of biochar is produced by using 18 $\mathrm{kg}$ of flower waste with a conversion efficiency of 55.5\%. It takes 30 minutes to complete one batch biochar production. However, Batch biochar production takes a lot of time. Thus, a separate research is undergoing to produce biochar from flower waste continuously. The measured lower heating value of the produced biochar is $26.54 \mathrm{MJ} / \mathrm{kg}$. Data has been collected from one of the flower farms in Ethiopia that is generating a daily dry flower waste of $560 \mathrm{~kg}$.

Thus, based on the result, approximately $310.8 \mathrm{~kg}$ of biochar can be generated daily. Thus, by adopting this innovative technology and producing biochar, the amount of flower waste is reduced from going to the landfill, energy is recovered from flower waste, income is generated from the selling of the produced biochar and the energy problems of the society is solved and finally environmental impact of the flower waste is reduced.

\subsection{Proximate Analysis of the Biochar}

Proximate analyses of the biochar produced from flower waste are determined experimentally as shown in Table 3 . The biochar produced shows a very high fixed carbon content of $67.91 \%$ and low content of volatile matter of $14.91 \%$. As a matter of fact the ash content $(10.775 \%)$ of the produced biochar is higher 
Table 3. Proximate analysis and calorific value of the produced charcoal.

\begin{tabular}{ccc}
\hline & Proximate Analysis \\
\hline Moisture Content (wt\%) & 6.405 \\
Ash Content (wt\%) & 10.775 \\
Volatile Content (wt\%) & 14.910 \\
Fixed Carbon (wt\%) & 67.910 \\
Total (wt\%) & 100.000 \\
& Heating Value & \\
Lower Heating Value & & $26.54 \mathrm{~J} / \mathrm{kg}$ \\
\hline
\end{tabular}

than the ash content (5.96\%) of the input feedstock. The results also show that the moisture content of the biochar is reduced as shown in Table 3. This is due to the fact that during pyrolysis process a portion of the moisture is removed.

\subsection{Estimation of Firewood Replaced}

Based on the experimental result, approximately $310.8 \mathrm{~kg}$ of biochar can be generated daily. Thus, considering lower heating value of $26.54 \mathrm{MJ} / \mathrm{kg}$ for the produced biochar, the amount of firewood replaced daily is approximately $392.2 \mathrm{~kg}$.

\subsection{Income Generated}

Income can be generated from the selling of the produced biochar. In Ethiopia, $50 \mathrm{~kg}$ of wood charcoal can be sold approximately 170 Ethiopian Birr. Thus, by selling $310.8 \mathrm{~kg}$ of the produced charcoal 1056.72 Ethiopian Birr can be obtained daily.

\subsection{Sensitivity Analysis}

\section{A. Effects of Temperature on Biochar Yield}

The biochar yield decreases with increasing pyrolysis temperature. This is due to the fact that the volatile mater is liberated as shown in Figure 10. biochar yield decreases by almost $9 \%$ when pyrolysis temperature increases from 400 to $500^{\circ} \mathrm{C}$. Besides, at high temperature biochar yield decreases, bio-oil and gas yield increases.

\section{B. Effect of Carbonization on Fixed Carbon Content}

During carbonization the fixed carbon content increases considerably from $14.395 \%$ (input biomass) to $67.91 \%$ C (biochar produced) showing that the biochar became more carbonaceous during carbonization.

\section{Conclusion}

In this paper, a novel pyrolysis technology to produce biochar has been designed, manufactured and tested. Characterization of the flower waste has also been done by estimating the ultimate and proximate analysis. Data have been collected from one of the flower farms in Ethiopia that is generating a daily dry flower waste of $560 \mathrm{~kg}$. Besides, the sizing of the reactor has been done by esti- 




Figure 10. Effects of temperature of the pyrolysis reactor on biochar yield.

mating the amount heat required to convert the biomass into biochar efficiently. Based on the result, a pyrolysis rector with $55.5 \%$ conversion efficiency has been obtained and approximately $310.8 \mathrm{~kg}$ of biochar can be generated daily. Besides, based on the experimental result, the lower heating value of the produced biochar is $26.54 \mathrm{MJ} / \mathrm{kg}$ and approximately $392.2 \mathrm{~kg}$ of firewood is replaced daily. In Ethiopia, $50 \mathrm{~kg}$ of wood charcoal can be sold approximately 170 Ethiopian Birr. Therefore, by selling $310.8 \mathrm{~kg}$ of the produced charcoal, 1056.72 Ethiopian Birr can be obtained daily. Thus, by adopting this innovative technology and producing biochar, the amount of flower waste is reduced from going to the landfill, energy is recovered from flower waste, income is generated from the selling of the produced biochar and the energy problems of the society is solved and finally environmental impact of the flower waste is reduced.

\section{References}

[1] Abayneh, T. (2013) Environmental Impacts of Floriculture Industry in Debrezeit Town: A Need For Strategic Environmental Assessment. Doctoral Dissertation, AAU.

[2] Lehmann, J., Gaunt, J. and Rondon, M. (2006) Bio-Char Sequestration in Terrestrial Ecosystems-A Review. Mitigation and Adaptation Strategies for Global Change, 11, 395-419. https://doi.org/10.1007/s11027-005-9006-5

[3] Lehmann, J. (2007) Bio-Energy in the Black. Frontiers in Ecology and the Environment, 5, 381-387. https://doi.org/10.1890/1540-9295(2007)5[381:BITB]2.0.CO;2

[4] Duku, M.H., Gu, S. and Hagan, E.B. (2011) Biochar Production Potential in Ghana-A Review. Renewable and Sustainable Energy Reviews, 15, 3539-3551. https://doi.org/10.1016/j.rser.2011.05.010

[5] Nsamba, H.K., Hale, S.E., Cornelissen, G. and Bachmann, R.T. (2015) Sustainable Technologies for Small-Scale Biochar Production-A Review. Journal of Sustainable Bioenergy Systems, 5, 10-31. https://doi.org/10.4236/jsbs.2015.51002

[6] Abdoulmoumine, N., Adhikari, S., Kulkarni, A. and Chattanathan, S. (2015) A Re- 
view on Biomass Gasification Syngas Cleanup. Applied Energy, 155, 294-307. https://doi.org/10.1016/j.apenergy.2015.05.095

[7] Richardson, Y., Blin, J. and Julbe, A. (2012) A Short Overview on Purification and Conditioning of Syngas Produced by Biomass Gasification: Catalytic Strategies, Process Intensification and New Concepts. Progress in Energy and Combustion Science, 38, 765-781. https://doi.org/10.1016/j.pecs.2011.12.001

[8] Lehmann, J. and Joseph, S., Eds. (2015) Biochar for Environmental Management: Science, Technology and Implementation. Routledge, New York, USA. http://www.biochar-international.org/projects/book

[9] Liu, N., Charrua, A.B., Weng, C.H., Yuan, X. and Ding, F. (2015) Characterization of Biochars Derived from Agriculture Wastes and Their Adsorptive Removal of Atrazine from Aqueous Solution: A Comparative Study. Bioresource Technology, 198, 55-62. https://doi.org/10.1016/j.biortech.2015.08.129

[10] Ahmad, M., Rajapaksha, A.U., Lim, J.E., et al. (2014) Biochar as a Sorbent for Contaminant Management in Soil and Water: A Review. Chemosphere, 99, 19-33. https://doi.org/10.1016/j.chemosphere.2013.10.071

[11] Cha, J.S., Park, S.H., Jung, S.C., Ryu, C., Jeon, J.K., Shin, M.C. and Park, Y.K. (2016) Production and Utilization of Biochar: A Review. Journal of Industrial and Engineering Chemistry, 40, 1-15. https://doi.org/10.1016/j.jiec.2016.06.002

[12] Wade, S.R., Nunoura, T. and Antal, M.J. (2006) Studies of the Flash Carbonization Process. 2. Violent Ignition Behavior of Pressurized Packed Beds of Biomass: A Factorial Study. Industrial \& engineering chemistry research, 45, 3512-3519. https://doi.org/10.1021/ie051374+

[13] Chen, W.H., Zhuang, Y.Q., Liu, S.H., Juang, T.T. and Tsai, C.M. (2016) Product Characteristics from the Torrefaction of Oil Palm Fiber Pellets in Inert and Oxidative Atmospheres. Bioresource Technology, 199, 367-374. https://doi.org/10.1016/j.biortech.2015.08.066

[14] Lee, E.H., Park, R.S., Kim, H., et al. (2016) Hydrodeoxygenation of Guaiacol over Pt Loaded Zeolitic Materials. Journal of Industrial and Engineering Chemistry, 37, 1821. https://doi.org/10.1016/j.jiec.2016.03.019

[15] Noor, N.M., Shariff, A. and Abdullah, N. (2012) Slow Pyrolysis of Cassava Wastes for Biochar Production and Characterization. Iranica Journal of Energy and Environment, 3, 60-65.

[16] Zhang, J., Liu, J. and Liu, R. (2015). Effects of Pyrolysis Temperature and Heating time on Biochar Obtained from the Pyrolysis of Straw and Lignosulfonate. Bioresource Technology, 176, 288-291. https://doi.org/10.1016/j.biortech.2014.11.011

[17] Lee, Y., Ryu, C., Park, Y.K., Jung, J.H. and Hyun, S. (2013) Characteristics of Biochar Produced from Slow Pyrolysis of Geodae-Uksae 1. Bioresource Technology, 130, 345-350. https://doi.org/10.1016/j.biortech.2012.12.012

[18] Ayllón, M., Aznar, M., Sánchez, J.L., Gea, G. and Arauzo, J. (2006) Influence of Temperature and Heating Rate on the Fixed Bed Pyrolysis of Meat and Bone Meal. Chemical Engineering Journal, 121, 85-96. https://doi.org/10.1016/j.cej.2006.04.013

[19] Bekele, M. and Girmay, Z. (2014) Reading through the Charcoal Industry in Ethiopia: Production, Marketing, Consumption and Impact. Forum for Social Studies.

[20] IEA WEO-2016. http://www.worldenergyoutlook.org/publications/weo-2016

[21] Bogale, W. (2009) Preparation of Charcoal Using Agricultural Wastes. Ethiopian Journal of Education and Sciences, 5, No. 1.

[22] WHO (2016) Household (Indoor) Air Pollution. http://www.who.int/indoorair/en/ 
Submit or recommend next manuscript to SCIRP and we will provide best service for you:

Accepting pre-submission inquiries through Email, Facebook, LinkedIn, Twitter, etc. A wide selection of journals (inclusive of 9 subjects, more than 200 journals)

Providing 24-hour high-quality service

User-friendly online submission system

Fair and swift peer-review system

Efficient typesetting and proofreading procedure

Display of the result of downloads and visits, as well as the number of cited articles Maximum dissemination of your research work

Submit your manuscript at: http://papersubmission.scirp.org/

Or contact jpee@scirp.org 